\title{
Scholars at War: Australasian Social Scientists, 1939-1945
}

Edited by Geoffrey Gray, Doug Munro and Christine Winter.

Australian National University E Press, Canberra, 2012.

ISBN 9781921862496 (Print version) ISBN 9781921862502 (Online)

Reviewed by Frank Bongiorno

This book is admirably designed for undergraduates, especially in medicine. What would they learn from it?

First, get yourself on to your university's senate as a student representative. Immediately put away the childish things of student affairs. Intervene in a major university controversy, preferably over an academic appointment, and make sure you win. Gain powerful friends and allies among the professoriate along the way. Drink deeply and often with an ever widening circle of friends and supporters. Buy a pipe. Use it to scratch your crotch. Get your friends and allies - the most powerful of them now transformed into remarkably cooperative patrons - to give you authority over others. Acquire office space, staff and filing cabinets. Find more friends and allies, preferably smart ones. Employ them all. Get yourself promoted. Get your friends promoted. Get more office space, more staff and more filing cabinets. Find new and even more powerful patrons. Keep scratching your groin with that pipe. Keep drinking, keep talking. Find new and even more powerful patrons. Get more office space, more staff and more filing cabinets.

Before long, like Alf Conlon, you might find yourself forming an administration in British Borneo, although you still won't have finished your medical degree. There are just three catches. You need someone to start a world war; war tends to open up opportunities for quick empire-building, and not only by megalomaniacs of the Napoleon or Hitler type. You also need more than just a dash of charisma, and a very great amount of chutzpah. And as this impressive collection of essays shows, you also need ideas, big ideas, and the capacity to articulate them in persuasively. As in comedy, delivery and timing count for lots.

It seems fitting to speak of comedy, since Cassandra Pybus' essay in this collection shows that good history can, just occasionally, be written as comedy, even if she sounds a tragic note at the end of her chapter on Alf Conlon, the ringmaster of the extraordinary circus eventually called the Directorate of Research and Civil Affairs. Its most famous product was the Ern Malley Affair, when two of Conlon's mates and employees, James McAuley and Harold Stewart, invented both a writer and a corpus of modernist poetry in Australia's most famous literary hoax, one aimed at embarrassing publisher Max Harris and discrediting the modernism he championed in his magazine, Angry Penguins.

Conlon and his mates are also supposed to have devised a plan for the Australian National University over a few drinks one night. There is, of course, an alluring legend here, and you always need to tread warily around such matters. This book - and perhaps especially the Conlon case - reminds us that war is an enabler and frequently a moment when intellectuals come into their own. It is also a reminder that the term 'intellectual' was initially pejorative and it's never quite managed to shake off its origins; the value of the work being carried out by Conlon and his friends was not accepted by all and as his patrons fell away, the knives came out. The collection shows that if many ordinary punters were indeed cynical about what it was that these boffins were doing, there was some justification for it. Perhaps some still agreed with W.H. Auden that

To the man-in-the-street who, I'm sorry to say,

Is a keen observer of life,

The word 'intellectual' suggests straight away

A man who's untrue to his wife. ${ }^{1}$ 
Several of the social scientists discussed in this collection went out of their way to avoid having to take on a combat role in the war - the New Zealanders, Neville Phillips and Dan Davin being the notable exceptions. For many of these intellectuals, this was a pretty good war, one that provided unique experiences and contacts, one that boosted careers. Some went on to distinguished post-war work; Ronald Berndt, Derek Freeman, J.W. Davidson, Neville Phillips and Dan Davin are examples. Others appeared a bit lost, at least initially; W.E.H Stanner's career seemed in neutral for some years, but he would go on to become one of Australia's most deeply and enduringly influential intellectuals. Conlon is a more tragic case; for him, the years of plenty came to an end in 1945. Camilla Wedgwood was similarly unable to build on her considerable wartime achievements. Both she and Conlon died prematurely.

The book focuses primarily, although not exclusively, on anthropologists. That, to some extent, reflects the interests of the editors - Geoff Gray, Doug Munro and Christine Winter but it also indicates the significant boost the war gave to the discipline of anthropology and its growing authority within the social sciences. The collection shows, for instance, the important role of A.P. Elkin's department in stimulating Australian academic sociology, and his own interest in questions of morale and propaganda. He even carried out a mini mass observation project, inspired by the famous British example.

Looking across the social sciences more generally, the Depression had given the economics profession its chance, and ANU ePress has in recent years published some distinguished historical writing on the rise of Australian economics. And while the economists continued to hold their own as Australian governments embraced Keynesian planning, the Pacific War exposed the government's need for a different kind of expertise, namely that offered by anthropologists and sociologists. There was, of course, the need for a knowledge that could be put to work for 'native affairs' as it was then called, at a time when it seemed Japan might invade and some observers worried that Australian Aboriginals might welcome them as liberators. Additionally there was Australia's role as a colonial power in the Territory of Papua and the Mandate of New Guinea, and New Zealand's involvement Western Samoa to consider. How could these mini-imperial powers discharge their responsibilities in a way that assisted indigenous development, prevented international criticism, and achieved consistency with the progressive and enlightened ideas the Labo(u)r governments of the 1940s liked to see as their own? Anthropology seemed like it might help provide the answers.

In his book The Empire Fractures: Anglo-Australian Conflict in the 1940s, Christopher Waters argued that in the 1940s an Anglo-Australian elite was displaced, at least temporarily, by a radical-nationalist coalition in relation to control of the Australian state. ${ }^{2}$ Waters has been much criticized by other scholars of Australian foreign policy for this opinion; critics point to the persistence of Britishness in Australian culture and policy through to the 1960s. Perhaps Waters did overstate the case, but Scholars at War suggests that he might have been more right than wrong. Here, among the Australian social scientists, we have a group of younger academics, experts and intellectuals, often with nationalist yearnings, who saw in the Labour governments of the 1940s the possibility of greater influence, in the cause of a more progressive and assertive Australia. There are indications here that similar things were happening in New Zealand, hints in the essays on Davidson, Davin and even Phillips, an arch-imperialist, that nationalist impulses increasingly mattered. The contrast with Elkin is revealing; he seems to come out of an older tradition of cultural liberalism rooted in Anglican spirituality, but it is telling that he was increasingly marginalized in terms of his influence on the state during the war. Stanner seems to occupy an intermediate position; to what extent was he hampered, in his dealings with the Labour governments, and in his willingness to work with Conlon and 'the boys', by his identification with the political conservatives? 
Stanner's wartime career illustrates another important point about the social sciences at this time: there remained considerable fluidity between the disciplines. Considering his postwar options, Stanner could still talk of becoming an anthropologist or an economist. Elkin and his students were boundary-riders between anthropology, sociology and psychology. Wedgwood's New Guinea labours brought together anthropology and education. Peter Hempenstall describes Derek Freeman's 'anthropological fieldwork with a psychological edge' (p.172). Conlon's outfit, in its various iterations, was an interdisciplinary institute that drew on history, anthropology, law, sociology, psychology and the bibliographical skills of the librarian, Ida Leeson. Davin explored the elusive relationship between history and fiction, even as he forged a career as an editor at Oxford University Press.

The problems of war and colonial administration seemed sufficiently complex to call for the insights of many disciplines as well as the kind of intellectual sufficiently adaptable to think across them, and so arrive at holistic solutions informed by empirical investigation and theoretical reflection. The demands of post-war reconstruction were similarly exacting; each social science discipline had something to contribute but none should dominate because human society was sufficiently complex to require many different kinds of knowledge. There was a trend towards specialization, yet also a sense that over-specialization would be selfdefeating. Specialists also needed to be flexible, open to the insights of other ways of seeing.

When academics write about academics you do get something like family history; we write about our teachers and supervisors, read the letters of our colleagues deposited in libraries, trace genealogies of who studied where that can seem rather like those biblical passages that set out at length just who begat whom. In one case in this collection, we have a literal family history: Jock Phillips writes of his father Neville. In other instances, the author had a direct association with the subject, or is removed from him, or her, by very few degrees of separation. Yet the essays in this collection are not examples of ancestor worship; this is critical history and biography, and a valuable contribution to the still neglected subject of Australasian intellectual history. Geoffrey Bolton's remark of over twenty years ago - 'So much Australian history is written by intellectuals, so little is written about them' - could no longer be made with the same confidence in the wake of studies such as Scholars at War. ${ }^{3}$

\footnotetext{
${ }^{1}$ Quoted in Don Anderson et al., 'What Is a Public Intellectual?', in Robert Dessaix, ed., Speaking their Minds: Intellectuals and the Public Culture in Australia, Sydney, 1998, p.3.

${ }^{2}$ Australian Scholarly Publishing, Melbourne, 1995.

${ }^{3}$ G.C. Bolton, 'Foreword', in John A. Moses, Prussian-German Militarism 1914-18 in Australian Perspective:

The Thought of George Arnold Wood, Bern, 1991, p.5.
} 